Journal of Economic, Business and Accounting (COSTING)

Volume 2 Nomor 1, Juli-Desember 2018

e-ISSN : 2597-5234

https://doi.org/10.31539/costing.v2i1.324

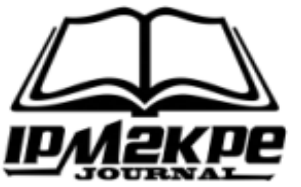

\title{
VARIAN ITEM PAKET CHAKI BIRTHDAY PARTY TERHADAP PERILAKU PEMBELIAN PAKET ULANG TAHUN ANAK DI RESTORAN CEPAT SAJI KFC JEMBER
}

\author{
ITEM VARIANT OF CHAKI BIRTHDAY PARTY PACKAGE TOWARD \\ PURCHASING BEHAVIOR OF CHILDREN'S BIRTHDAY PACKAGES \\ AT FAST FOOD RESTAURANT KFC JEMBER
}

\author{
Febrina Gerhani \\ IKIP PGRI Jember \\ febri2018@gmail.com
}

\begin{abstract}
Marketing activities are required to always be creative and innovative in competing to get interest from buyers. This study aims to determine the relationship between variants of the Chaki Birthday Party KFC Jember item on the behavior of purchasing children's birthday packages at KFC Jember fast food restaurants. The number of sample is 132 people with parents as the sample who filled in the questionnaire as a representative of the behavior shown by children towards the item variants of Chaki Birthday Party KFC Jember package. The research instrument was in the form of a questionnaire to determine the assessment of item variants of Chaki Birthday Party package and children's buying behavior. Simple statistical procedures were conducted in the form of percentage calculation and data descriptions to analyze data. The results of this study indicated that the most children behavior in determine buying activity were included in habitual buying behavior of $69.28 \%$. In relation to the item variants offered and promoted by KFC Jember, $70.37 \%$ students showed interest and enthusiasm for the Chaki Birthday Party package item. Therefore, the interest and enthusiasm for Chaki Birthday Party package item variants encourages the buying behavior caused by habit due to the comfort and loyalty of children as consumers or potential consumers of the Chaki Birthday Party package.
\end{abstract}

Keywords: Item Variants, Chaki Birthday Party KFC Package, Children Buying Behavior, Selling Strategy

\begin{abstract}
ABSTRAK
Kegiatan pemasaran dituntut untuk senantisa kreatif dan inovatif dalam bersaing memperoleh minat dari para pembeli. Penelitian ini bertujuan untuk mengetahui hubungan antara varian item Chaki Birthday Party KFC Jember terhadap perilaku pembelian paket ulang tahun anak di restoran cepat saji KFC Jember. Jumlah sample yaitu 132 orang dengan orang tua sebagai sample yang akan mengisi angket sebagai perwakilan dari perilaku yang ditunjukkan anak-anak terhadap varian item paket Chaki Birthday Party KFC Jember. Instrumen penelitian berupa angket untuk mengetahui penilaian varian item paket Chaki Birthday Party dan perilaku pembelian anak-anak. Simple statistical procedure berupa perhitungan persentase dan deskripsi data dilakukan untuk menganalisis data.Hasil penelitian ini yaitu berupa perilaku mayoritas anak-anak dalam menetukan perilaku pembelian dikategorikan sebagai perilaku pembelian karena kebiasaan sebesar 69.28\%.Sehubungan dengan varian item yang ditawarkan dan dipromosikan pihak KFC Jember
\end{abstract}


70.37\% menunjukkan ketertarikan dan antusias pada varian item paket Chaki Birthday Party.Sehingga ketertarikan dan antusias terhadap varian item paket Chaki Birthday Party mendorong perilaku pembelian karena kebiasaan karena bentuk kenyamanan dan sisi loyalitas anak-anak sebagai konsumen atau calon konsumen paket Chaki Birthday Party.

Keywords: Varian Item, Paket Chaki Birthday Party KFC, Perilaku Pembelian Anak, Strategi Penjualan

\section{PENDAHULUAN}

Angka penjualan yang tinggi merupakan impian semua pelaku bisnis. Dengan memperoleh hasil penjualan yang tinggi tentunya akan meningkatkan keuntungan dari pelaku bisnis. Hal ini tentunya berdampak positif bagi kelangsungan usaha untuk tetap melaksanakan pergerakan bisnis dalam jangka waktu yang Panjang.Tentunya, semua pebisnis ingin mempertahankan usahanya tanpa mengalami kemerosotan ataupun kerugian.Menyikapi kemungkinan kemungkinan tersebut, mempertahankan prestasi penjualan yang baik tentunya bukan hal yang mudah.Para pebisnis harus memikirkan dan menerapkan trik-trik yang dapat meningkatkan penjualan baik barang atau penyediaan jasa yang dilakukan.

Pada masa sekarang, manusia telah banyak sekali melakukan inovasi di berbagai bidang termasuk dalam bisnis jual beli baik barang dan jasa. Usaha ini dapat dalam bentuk penjualan produk pakaian, kosmetik, furniture hingga urusan perut yaitu makanan.Saat ini, bisnis makanan sangat digandrungi oleh banyak pihak dalam masyarakat seiring minat konsumsi masyarakat yang meningkat terutama kepada mkanan-makanan yang Instragamable.Instagrambale sendiri adalah sifat yang melekat pada sebuah objek yang diabadikan gambarnya dalam sebuah foto dan dapat di unggah melalui media sosial Instagram.Instagram saat ini merupakan salah satu media yang banyak sekali dijadikan ajang promosi dan penjualan barang dan jasa, termasuk makanan( Ratnasari, Hamdan, dan Julia, 2017). Bukan hanya Instagram, media sosial lainnya pun sangat mempengaruhi seseorang mencoba menu makanan. Oleh karena itu, para pebisnis pun berlomba-lomba untuk menciptakan kreasi menu baru atau menu modifikasi yang dapat menarik minat konsumen.

Dalam bisnis makanan, menu bukanlah satu-satunya. Hal lain yang penting adalah kegiatan pemasaran/marketing yang harus kreatif sehingga meningkatkan minat pembeli. Banyak restoran yang menawarkan berbagai macam menu utama hingga menu yang terlihat ekonomis dalam bentuk paket.Berbagai macam pake ditawarkan untuk berbagai kebutuhan para konsumen untuk tujuan yang beragam.Salah satu restoran cepat saji KFC (Kentucky Fried Chicken), contohnya, menawarkan beragam paket sajian untuk menarik beragam lapisan masyarakat.KFC merupakan salah satu perusahaan waralaba cepat saji yang berasal dari Amerika.KFC Indonesia dipegang oleh PT Fast Food Indonesia Tbk yang didirikan oleh keluarga Gelael pada tahun 1978.Bagi para pekerja kantoran, mereka menawarkan paket breakfast yang praktis untuk sarapan.Bagi pecinta kuliner unik mereka juga menawarkan paket ayam goreng saos coklat, misalnya.Untuk konsumen yang 
akan merayakan sebuah selebrasi seperti acara ulang tahun anak, KFC menawarkan beberapa varian paket ultah anak seperti paket tematik, dan paket funtastic.

Penawaran paket sajian dalam bentuk paket harga serta penawaran-penawaran yang dikemas dalam satu kesatuan paket yang ditawarkan merupakan alat yang digunakan dalam sebuah kegiatan promosi penjualan. Harga paket adalah salah satu cara untuk mendorong calon pembeli (Suharyadi, Nugroho, Purwanto S. K dan Faturohman, 2007). Industri makanan cepat saji memanglah menjadi industri yang paling dipengaruhi oleh tren harga paket seperti beli dua gratis satu atau beli makanan dapat air mineral (Churcill, 2005). Bentuk promosi ini terbilang kreatif mengingat konsumen yang ditargetkan adalah anak-anak. Meskipun yang melakukan transaksi adalah para orang tua namun anak-anak juga menentukan keputusan pembelian karena mereka kemungkinan akan melihat benda-benda yang ditawarkan dalam paket acara mereka. Oleh karena itu penting dilakukannya penelitian ini untuk mengetahui dan membuktikanada atau tidaknya hubungan antaravariasi paket sajian yang ditawarkan KFC Jember kepada konsumen dan perilaku pembelian paket ultah anak.

\section{Perilaku Pembelian}

Perilaku pembelian merupakan sebuah perilaku yang ditunjukkan oleh konsumen ketika akan membeli sebuah produk. Perilaku merupakan sebuah tindakan yang dilibatkan ketika membuat suatu keputusan (Setiadi, 2015:341). Penjual produk biasanya akan mempelajari perilaku konsumen mereka untuk menentukan strategi apa yang sebaiknya diterapkan untuk lebih menarik minat mereka terhadap produk yang ditawarkan/dijual.

Para ahli mengembangkan beragam model tentang perilaku konsumen. Menurut Kotler (dikutip dalam Simamora, 2008), keputusan seseorang atas merk, kategori produk, tempat untuk didatangi, waktu pembelian dan jumlah pembelian, merupakan hasil dari rangsangan (stimuli) yang berasal dari luar dirinya, yang diolah dalam diri konsumen.Kotler juga membedakan empat tipe perilaku pembelian konsumen berdasarkan pada tingkat keterlibatan pembeli dan tingkat perbedaan di antara merk, yaitu perilaku membeli yang rumit, perilaku membeli untuk mengurangi ketidakcocokan, perilaku membeli berdasarkan kebiasaan, dan perilaku pembeli yang mencari keragaman.

Dalam melakukan pembelian, ada kebutuhan-kebutuhan yang mempengaruhi sebagian besar keputusan pembelian yaitu kebutuhan ekonomi dan pengaruh psikologis.Kebutuhan ekonomi seperti pemenuhan nilai dengan mencari harga terendah, membayar lebih untuk mendapatkan kemudahan, efisiensi penggunaan, keandalan penggunaan dan peningkatan penghasilan (Cannon, Perreault, Jr dan McCarthy. 2008).

\section{Strategi Penjualan}

Kegiatan penjualan merupakan kegiatan menjual barang atau jasa untuk mendapatkan keuntungan.Keuntungan yang diperoleh pada kegiatan-kegiatan transaksi berpengaruh besar terhadap kelangsungan suatu usaha.Oleh karena itu, para pelaku bisnis haruslah berusaha memikirkan dan melaksanakan berbagai macam strategi yang sesuai untuk meningkatkan target penjualan demi mendapatkan keuntungan yang memuaskan.Namun, tidak semua pelaku 
bisnis atau perusahaan dapat menyusun strategi penjualan dengan baik meskipun mereka mampu menyusun perencanaan (Mulia, 2015:106).

Strategi penjualan yaitu dapat berupa promosi penjualan dan periklanan.Program promosi penjualan sangat penting karena merupakan bagian dari rencana penjualan sebuah perusahaan. Tujuan dibuatnya program promosi ini adalah untuk mendapatkan pedoman tentang cara perusahaan mencapai tujuan/target bisnis (Haryadi, 2005).

Menurut Rangkuti (2009:28), tujuan promosi hendaknya disesuaikan dengan tingkatan pengetahuan yang dimiliki pelanggan. Terdapat tiga tujuan promosi, yaitu, memberikan informasi, mengubah sikap dan keyakinan atau perasaan dan menstimulasi agar pelanggan melakukan pembelian.Contohnya, promosi yang dilakukan melalui iklan KFC di televisi yaitu bertujuan memberikan informasi tentang menu baru yang ditawarkan. Kemudian ketika pemirsa televisi melihat iklan menu baru KFC dengan saus unik yang menggoda selera disanalah sikap konsumen akan berubah menjadi memiliki kecenderungan positif hingga akhirnya berkeinginan membeli makanan KFC dengan menu baru.

Strategi promosi juga banyak mengalami perubahan akibat dari perubahan dan perkembangan teknologi. Saat ini strategi promosi lebih banyak mengarah kepada strategi komunikasi, produk teknologi dan komunikasi lebih ekonomis dan praktis bagi hidup manusia (Rangkuti, 2009b:4).Orang-orang pun lebih banyak mengenal produk dari sosial media seperti Facebook, Instagram, Youtube dan situs-situs belanja online yang sangat merebak bak jamur di musim
hujan.KFC pun telah memiliki akun media sosial untuk memasarkan produknya selain situs resmi www.kfcku.com.

\section{Anak-anak sebagai Target Penjualan}

Konsumen barang atau jasa tidak dibatasi oleh usia ataupun jenis kelamin serta latarbelakang sosial apapun. Oleh karena itu, anak-anak pun merupakan salah satu target penjualan barang atau jasa.Para pelaku usaha pun telah menjadikan anak-anak sasaran promosi dan penjualan yang sangat memberikan dampak positif pada kegiatan jual beli.Pertimbangannya yaitu anak-anak dapat memonopoli pembelian yang dilakukan oleh orang tua.Berdasarkan data, di Amerika sekitar 57 juta anak usia remaja menghabiskan sekitar \$100 miliar tiap tahun dengan membelanjakan uang keluarga untuk membeli makanan, jajanan, minuman, video, produk elektronik, mainan, film, olahraga, baju dan sepatu. Selanjutnya, anak-anak usia 12 kebawah juga menghabiskan \$11 miliar untuk belanja makanan dan juga alat rumah tangga lainnya (Beder, 1998).

Terlihat dari konsumsi anak-anak, pelaku bisnis gencar melibatkan penjualan makanan yang disertai dengan perlengkapan sekolah dan mainan yang menarik minat anak secara visual. Ketertarikan visual berupa variasi item, disain produk serta tema up-to-date ditawarkan kepada konsumen anak-anak untuk meningkatkan pembelian makanan seperti fast food.Hal ini tentu saja dapat dikaitkan pada sistem pengolahan informasi anak dalam sistem kognitif otak yang dapat mempengaruhi sikap pembelian barang dalam tingkah laku yang terkontrol (controlled behavior) (Hutchinson, Lu \& Weingarten, n.d).oleh karena itu, target konsumen yang merupakan anak-anak dirasakan sebagai 
strategi efektif dalam kegiatan promosi dan penjualan produk.

\section{Restoran Cepat Saji KFC}

Usaha restoran cepat saji cukup menuai kesuksesan dibuktikan dengan adanya beberapa merek restoran ternama yang muncul di berbagai wilayah tersebar di seluruh Indonesia.Sebut saja $A W, C F C$, McDonald, KFC, Pizza Hut, dan lainnya.Umumnya restoran tersebut hadir di wilayah perkotaan hingga wilayah kota kabupaten. Restoran ini cukup diminati masyarakat dikarenakan trend makanan modern dengan penyajian cepat dan dengan kondisi ruang yang nyaman dengan beragam dekorasi serta Air Conditioner.

Disamping praktis, orang yang makan ditempat ini memiliki kecenderungan prestige yang tinggi dalam masyarakat dikarenakan sajiannya adalah makanan yang modern-kebarat-baratan dengan harga yang lebih tinggi dibandingkan dengan makanan yang ada di warung tradisional. Disamping itu, banyak paket yang ditawarkan dengan harga yang beragam mulai dari paket goceng dengan harga Rp. 5000 saja hingga yang lebih mahal hingga ratusanribu rupiah dalam paket combo (www.kfcku.com, diakses pada 10 Maret 2017).

Salah satu perusahaan waralaba cepat saji yaitu KFC atau Kentucky Fried Chicken yang berasal dari Amerika.KFC Indonesia dipegang oleh PT Fast Food Indonesia Tbk yang didirikan oleh keluarga Gelael pada tahun 1978 (http://www.kfcindonesia.com/kegiatan-u saha-perusahaan, diakses pada 15 Maret 2017).Target restoran ini adalah seluruh lapisan masyarakat, melihat dari varian menu yang ditawarkan.Varian menu juga menjangkau anak-anak sebagai salah satu tipe konsumen KFC.Paket menu untuk anak serta penawaran paket perayaan ulang tahun menunjukkan KFC menganggap penting kontribusi anak-anak sebagai konsumennya.Hal ini terlihat dari tawaran pake ultah yang terdiri dari dua jenis paket.Chaki Birthday Party dengan duaa jenis paket yang ditawarkan berupa paket tematik, dan paket funtastic. Jika melihat bagian menu di situs www.kfcku.com maka ada pilihan kids yang memang di khususkan untuk kids party (pesta untuk anak-anak).

Pada pilihan paket thematic varian item yang ditawarkan adalah tema Justice league yang sedang popular saat ini berisi backdrop, dekorasi, sound system, MC, Chaki mascot, Magic balloon, stick up balloon, kartu undangan, topi ultah, guest board, dan paket makan. Bonus yang ditawarkan yaitu tas justice league gratis serta pudding gratis untuk setiap sajian makanan. Paket ini sangat menarik karena bertemakan pahlawan yang sedang dikenal pada saat ini.Namun, ada kemungkinan anak perempuan kurang menyukainya karena tema ini bertema superhero yang lebih cocok untuk anak laki-laki.

Paket selanjutnya adalah paket Funtastic dengan varian item MC, dekorasi balon lengkap, Backdrop, topi ultah, undangan, buku tamu, hadiah games, balon stick-up, hadiah special si ultah, souvenir untuk tamu, mascot chaki dan sajian makanan. Bonus yang ditawarkan yaitu hadiah games, hadiah special si ultah, souvenir untuk tamu dan pudding untuk setiap sajian makanan. Paket ini kemungkinan sesuai untuk anak laki-laki dan juga perempuan karena tidak bertema khusus. 


\section{METODE PENELITIAN}

Penelitian ini merupakan penelitian survei dengan pendekatan kuantitatif dengan pengumpulan data melalui penyebaran angket kepada para orang tua siswa Sekolah Dasar yang ada di tiga kecamatan yang merupakan daerah perkotaan kabupaten Jember.Objek penelitian adalah beragam item yang ditawarkan dalam beberapa paket ultah KFC seperti paket tematik, dan paket funtastic.

Populasi penelitian ini adalah orang tua dari anak-anak berusia antara 6-12 tahun yang bersekolah di Sekolah Dasar Negeri kabupaten Jember yang ditemui secara accidental atau secara tiba-tiba saat orang tua dan anak melakukan pembelian di KFC Jember dalam kurun waktu. Jumlah perolehan sample yaitu 138 orang dengan orang tua sebagai sample yang akan mengisi angket sebagai perwakilan dari perilaku yang ditunjukkan anak-anak terhadap varian item paket Chaki Birthday Party KFC Jember.

Teknik pengumpulan data yang dilakukan adalah melalui penyebaran angket yaitu seperangkat pertanyaan yang diajukan kepada responden (Sugiyono, 2006).Studi survei dengan penggunaan angket tersebut adalah untuk memberi gambaran mengenai pengaruh varian item paket Chaki Birthday Party yang ditawarkan KFC Jember terhadap perilaku pembelian paket ultah anak.Angket berisi pertanyaan mengenai perilaku pembelian sebanyak 20 pernyataandan pernyataan tentang varian item sebanyak 15 pernyataan.masing-masing poin pernyataan akan dinilai berdasarkan skala Likert dengan opsi sangat setuju (SS), setuju (S), Tidak setuju (TS) dan sangat tidak setuju (STS).
Teknik analisis data dilakukan dengan menggunakan statistic deskriptif yang disajikan melalui table, grafik, presentase, perhitungan standar deviasi (Sugiyono, 2006) serta analisis korelasi.

Data yang terjaring hanya 132 dari 138 angket yang tersebar dengan alasan para orang tua tidak mengembalikan angket dan sulit ditemui serta adanya pengisian angket yang tidak sesuai.

\section{HASIL DAN PEMBAHASAN}

Analisis data angket

Analisis data angket terbagi menjadi dua yaitu analisis data varian angket Chaki Birthday Partydan analisis perilaku pembelian paket ulang tahun anak di KFC Jember.

\section{Analisis data varian paket Chaki Birthday Party KFC Jember}

Data varian paket Chaki Birthday Party diperoleh melalui angket yang disebar kepada 138 orang tua SD Negeri Kecamatan Patrang.Namun hanya 132 angket yang terkumpul dan terisi secara lengkap.

Jawaban dan kecenderungan pilihan informan terhadap pernyataan mengenai variable varian paket Chaki Birthday Partydinyatakan dengan penggunaan Likert Scale yaitu $1=$ sangat tidak setuju, 2 = tidak setuju, $3=$ setuju, 4 $=$ sangat setuju.

Pernyataan pada angket akan memberikan data informasi pendapat para informan sebagai masyarakat sekaligus konsumen/calon konsumen restoran cepat saji KFC Jember mengenai varian paket Chaki Birthday Party. Ada 20 angket yang berisi pernyataan mengenai perilaku pembelian konsumen terhadap varian paket Chaki Birthday Party sebagai sumber data dari para informan. 
Berikut adalah hasil data angket yang menyatakan penilaian kepada varian Paket Chaki Birthday Party KFC Jember yang ditampilkan dalam persentase yang dikategorikan menjadi Setuju dan Sangat setuju serta penilaian Tidak Setuju dan Sangat tidak Setuju.

Tabel 1.Data Angket Varian Paket Chaki Birthday Party KFC Jember

\begin{tabular}{|c|c|c|c|}
\hline No & Angket & $\begin{array}{c}\text { Penilaian } \\
\text { Setuju dan } \\
\text { Sangat } \\
\text { Setuju }\end{array}$ & $\begin{array}{c}\text { Penilaian } \\
\text { Tidak } \\
\text { Setuju dan } \\
\text { Sangat } \\
\text { Tidak } \\
\text { Setuju } \\
\end{array}$ \\
\hline 1 & $\begin{array}{lr}\text { Anak } & \text { saya } \\
\text { mengetahui paket } \\
\text { Chacki Birthday } \\
\text { Party KFC Jember. }\end{array}$ & $29.3 \%$ & $70.7 \%$ \\
\hline 2 & $\begin{array}{l}\text { Anak saya mengenal } \\
\text { karakter Chacki } \\
\text { KFC. }\end{array}$ & $25.7 \%$ & $74.3 \%$ \\
\hline 3 & \begin{tabular}{l}
\multicolumn{3}{l}{ Saya dan anak saya } \\
menyadari adanya \\
paket Chacki \\
Birthday Party KFC \\
Jember.
\end{tabular} & $48.8 \%$ & $51.2 \%$ \\
\hline 4 & $\begin{array}{lr}\text { Anak saya tertarik } \\
\text { dengan penawaran } \\
\text { paket } & \text { Chacki } \\
\text { Birthday Party KFC. }\end{array}$ & $68.7 \%$ & $31.3 \%$ \\
\hline 5 & $\begin{array}{l}\text { Saya belum pernah } \\
\text { memesan paket } \\
\text { Chacki Birthday } \\
\text { party tetapi anak } \\
\text { saya tertarik dengan } \\
\text { paket yang } \\
\text { ditawarkan. }\end{array}$ & $72.3 \%$ & $27.7 \%$ \\
\hline 6 & $\begin{array}{l}\text { Ketika mempelajari } \\
\text { paket Chacki } \\
\text { Birthday party anak } \\
\text { saya sangat antusias } \\
\text { dengan penawaran } \\
\text { paket yang di } \\
\text { tunjukkan dalam } \\
\text { brosur. }\end{array}$ & $79.2 \%$ & $20.8 \%$ \\
\hline 7 & $\begin{array}{lr}\text { Anak saya } & \text { terarik } \\
\text { pada paket } & \text { Chacki } \\
\text { Birthday Party KFC } \\
\text { Jember } & \text { karena } \\
\text { kreatifitas } & \text { dan } \\
\text { inovasinya. } & \\
\end{array}$ & $64.4 \%$ & $35.6 \%$ \\
\hline 8 & $\begin{array}{lr}\text { Anak } & \text { saya } \\
\text { menyukai } & \text { semua } \\
\text { varian item } & \text { dalam }\end{array}$ & $86.9 \%$ & $13.1 \%$ \\
\hline
\end{tabular}

\begin{tabular}{|c|c|c|c|}
\hline & $\begin{array}{l}\text { paket Chacki } \\
\text { Birthday Party KFC } \\
\text { Jember }\end{array}$ & & \\
\hline 9 & $\begin{array}{l}\text { Saya menganggap } \\
\text { paket Chacki } \\
\text { Birthday Party KFC } \\
\text { Jember bagus untuk } \\
\text { pembelajaran anak. }\end{array}$ & $67.8 \%$ & $32.2 \%$ \\
\hline 10 & $\begin{array}{l}\text { Anak saya mengenal } \\
\text { karakter Chacki } \\
\text { KFC }\end{array}$ & $74.8 \%$ & $25.2 \%$ \\
\hline 11 & $\begin{array}{l}\text { Anak saya sangat } \\
\text { senang dengan } \\
\text { varian item paket } \\
\text { Chacki Birthday } \\
\text { Party KFC Jember }\end{array}$ & $79.3 \%$ & $20.7 \%$ \\
\hline 12 & $\begin{array}{l}\text { Varian item paket } \\
\text { Chacki Birthday } \\
\text { Party KFC Jember } \\
\text { membuat pesta anak } \\
\text { saya meriah. }\end{array}$ & $47.5 \%$ & $52.5 \%$ \\
\hline 13 & $\begin{array}{lr}\text { Anak } & \text { saya } \\
\text { menyukai } & \\
\text { bonus-bonus } & \text { yang } \\
\text { ditawarkan } & \text { dalam } \\
\text { paket } & \text { Chacki } \\
\text { Birthday Party } & \text { KFC } \\
\text { Jember } & \end{array}$ & $68.6 \%$ & $31.4 \%$ \\
\hline 14 & $\begin{array}{l}\text { Anak saya } \\
\text { menyukai tema yang } \\
\text { ditawarkan Chacki } \\
\text { Birthday Party KFC } \\
\text { Jember. } \\
\end{array}$ & $87.6 \%$ & $12.4 \%$ \\
\hline 15 & $\begin{array}{lr}\text { Anak saya } & \text { hanya } \\
\text { tertarik pada } & \text { varian } \\
\text { item } & \text { yang } \\
\text { ditawarkan } & \text { pada } \\
\text { Chacki } & \text { Birthday } \\
\text { Party KFC Jember } \\
\text { dari pada perayaan } \\
\text { ultah. }\end{array}$ & $53.7 \%$ & $46.3 \%$ \\
\hline
\end{tabular}

Sumber : Data Olahan (2018)

Dari hasil analisis angket, dapat disimpulkan bahwa item pernyataan yang menyebutkan tentang ketertarikan, antusias dan kualitas mengenal varian item yang ditawarkan pada paket Chaki Birthday Party.Item yang menunjukkan pada ketertarikan dan antusias anak pada varian item Chaki Birthday Party KFC Jember berjumlah 11 item dengan perolehan angka $70.37 \%$ informan memilih nilai setuju dan sangat 
setuju.Sedangkan sebesar $29.63 \%$ informan memilih jawaban tidak setuju dan sangat tidak setuju.Hal ini memperlihatkan adanya perolehan nilai yang cukup tinggi yang menunjukkan bahwa anak-anak sebagai konsumen KFC berupa Chaki Birthday Partymenyatakan ketertarikan dan antusiasnya ketika mendapat penawaran dan juga ketika melakukan pembelian.

Dari hasil angket yang telah dijawab orang tua untuk mewakili anak mereka sebagai konsumen KFC dapat diketahui bahwa $44.65 \%$ hasil angket menyatakan bahwa orang tua menyatakan setuju dan sangat setuju bahwa anak mereka mengenal varian item dan karakter Chaki Birthday party. Sedangkan jawaban untuk tidak setuju dan sangat tidak setuju mengenal varian item dan karakter Chaki sebesar $55.35 \%$.

\section{Analisis Data Angket Perilaku Pembelian oleh Konsumen Anak-Anak}

Berikut adalah hasil data angket yang menyatakan penilaian kepada varian Paket Chaki Birthday Party KFC Jember yang ditampilkan dalam persentase yang dikategorikan menjadi Setuju dan Sangat setuju serta penilaian Tidak Setuju dan Sangat tidak Setuju.

Tabel 2.Data Angket Perilaku Pembelian oleh Konsumen Anak-Anak

\begin{tabular}{|c|c|c|c|}
\hline No & Angket & $\begin{array}{c}\text { Penilaian } \\
\text { Setuju } \\
\text { dan } \\
\text { Sangat } \\
\text { Setuju } \\
\end{array}$ & $\begin{array}{c}\text { Penilaian } \\
\text { Tidak Setuju } \\
\text { dan Sangat } \\
\text { Tidak Setuju }\end{array}$ \\
\hline 1 & $\begin{array}{lr}\text { Saya dan anak saya } \\
\text { tidak } & \text { terlalu } \\
\text { memperdulikan banner } \\
\text { dan label promosi } \\
\text { paket Chaki Birthday } \\
\text { Party KFC Jember } \\
\text { yang ada di dinding } \\
\text { KFC Jember. }\end{array}$ & $73.8 \%$ & $26.2 \%$ \\
\hline 2 & $\begin{array}{lll}\text { Anak saya lebih } \\
\text { mengenal paket } & \text { ulang }\end{array}$ & $63.7 \%$ & $36.3 \%$ \\
\hline
\end{tabular}

\begin{tabular}{|c|c|c|c|}
\hline & $\begin{array}{l}\text { tahun yang ditawarkan } \\
\text { oleh restoran lainnya. }\end{array}$ & & \\
\hline 3 & $\begin{array}{l}\text { Ketika pihak KFC } \\
\text { mencoba menawarkan } \\
\text { paket Chaki Birthday } \\
\text { Party KFC Jember } \\
\text { ketika saya dan anak } \\
\text { saya, anak saya } \\
\text { langsung antusias } \\
\text { kepada varian item } \\
\text { yang ditawarkan. }\end{array}$ & $78.7 \%$ & $21.3 \%$ \\
\hline 4 & $\begin{array}{l}\text { Meskipun ditawarkan } \\
\text { paket Chaki Birthday } \\
\text { Party KFC Jember } \\
\text { saya dan anak saya } \\
\text { tidak langsung tertarik } \\
\text { oleh penawarannya. }\end{array}$ & $53.6 \%$ & $46.4 \%$ \\
\hline 5 & $\begin{array}{lr}\text { Setelah mendapatkan } \\
\text { penawaran paket Chaki } \\
\text { Birthday Party KFC } \\
\text { Jember, anak saya } \\
\text { menunjukkan rasa } \\
\text { penasarannya dengan } \\
\text { bertanya } \\
\text { menuturkan } \\
\text { keinginannya membeli } \\
\text { paket Chaki Birthday } \\
\text { Party KFC Jember. }\end{array}$ & $66.2 \%$ & $33.8 \%$ \\
\hline 6 & $\begin{array}{l}\text { Anak saya tertarik } \\
\text { dengan varian paket } \\
\text { Chaki Birthday Party } \\
\text { KFC Jember karena } \\
\text { merasa terpengaruh } \\
\text { dengan penyampaian } \\
\text { promosi pihak KFC } \\
\text { Jember. }\end{array}$ & $46.6 \%$ & $53.4 \%$ \\
\hline 7 & $\begin{array}{l}\text { Anak saya mengenal } \\
\text { varian item dalam } \\
\text { paket Chaki Birthday } \\
\text { Party KFC Jember } \\
\text { dengan hanya melihat } \\
\text { promosinya di banner } \\
\text { dan dinding KFC } \\
\text { Jember. }\end{array}$ & $26.8 \%$ & $73.2 \%$ \\
\hline 8 & $\begin{array}{l}\text { Anak saya berpikir } \\
\text { bahwa paket ultah } \\
\text { restoran lain lebih } \\
\text { menarik dari pada } \\
\text { paket Chaki Birthday } \\
\text { Party KFC Jember. }\end{array}$ & $37.5 \%$ & $62.5 \%$ \\
\hline 9 & $\begin{array}{l}\text { Ketika mendapatkan } \\
\text { penawaran dari pihak } \\
\text { KFC Jember, anak } \\
\text { saya berusaha } \\
\text { membandingkan } \\
\text { dengan paket ultah dari } \\
\text { restoran lain. }\end{array}$ & $84.8 \%$ & $15.2 \%$ \\
\hline 10 & Penawaran dekorasi & $87.8 \%$ & $12.2 \%$ \\
\hline
\end{tabular}




\begin{tabular}{|c|c|c|c|}
\hline & $\begin{array}{l}\text { ultah seperti backdrop, } \\
\text { topi ultah, buku tamu, } \\
\text { aneka balon, dan } \\
\text { mascot Chaki adalah } \\
\text { varian item yang } \\
\text { menarik dalam sebuah } \\
\text { acara ultah. }\end{array}$ & & \\
\hline 11 & $\begin{array}{l}\text { Anak saya tertarik } \\
\text { dengan varian paket } \\
\text { Chaki Birthday Party } \\
\text { KFC Jember yang } \\
\text { memberikan hiburan } \\
\text { dan pembelajaran. }\end{array}$ & $74.2 \%$ & $25.8 \%$ \\
\hline 12 & $\begin{array}{l}\text { Anak saya menyadari } \\
\text { bahwa varian item } \\
\text { yang ditawarkan dalam } \\
\text { paket Chaki Birthday } \\
\text { Party KFC Jember } \\
\text { akan membuat pesta } \\
\text { meriah } \\
\text { menyenangkan. }\end{array}$ & $77.4 \%$ & $22.6 \%$ \\
\hline 13 & $\begin{array}{lr}\text { Bonus yang } \\
\text { ditawarkan pada paket } \\
\text { Chaki Birthday Party } \\
\text { KFC Jember menarik } \\
\text { anak saya karena dapat } \\
\text { digunakan untuk } \\
\text { bermain. }\end{array}$ & $86.1 \%$ & $13.9 \%$ \\
\hline 14 & $\begin{array}{l}\text { Anak saya menyatakan } \\
\text { bahwa ia akan } \\
\text { merayakan ultah lagi } \\
\text { setelah perayaan ultah } \\
\text { di KFC Jember karena } \\
\text { banyak hadiah yang } \\
\text { didapatkan. }\end{array}$ & $75 \%$ & $25 \%$ \\
\hline 15 & $\begin{array}{l}\text { Anak saya sudah lebih } \\
\text { dari sekali melakukan } \\
\text { pembelian varian dan } \\
\text { paket Chaki Birthday } \\
\text { Party KFC Jember. }\end{array}$ & $33.7 \%$ & $66.3 \%$ \\
\hline 16 & $\begin{array}{l}\text { Anak saya dan saya } \\
\text { belum pernah } \\
\text { memesan paket Chaki } \\
\text { Birthday party tetapi } \\
\text { anak saya tertarik } \\
\text { dengan paket yang } \\
\text { ditawarkan. }\end{array}$ & $68.3 \%$ & $31.7 \%$ \\
\hline 17 & $\begin{array}{lr}\text { Anak saya selektif } \\
\text { ketika memilih tempat } \\
\text { untuk merayakan } \\
\text { ultahnya. }\end{array}$ & $70.3 \%$ & $29.7 \%$ \\
\hline 18 & $\begin{array}{l}\text { Ketika ditawarkan } \\
\text { paket dan varian Chaki } \\
\text { Birthday party KFC } \\
\text { Jember, anak saya } \\
\text { ingin melakukan } \\
\text { perayaan ultahnya di } \\
\text { KFC Jember }\end{array}$ & $72.2 \%$ & $27.8 \%$ \\
\hline
\end{tabular}

\begin{tabular}{llll}
\hline 19 & Setelah melakukan $34.2 \%$ & $65.8 \%$ \\
pembelian paket dan & & \\
varian Chaki Birthday & & \\
party KFC Jember & & \\
anak saya ingin & & \\
melakukan perayaan di & & \\
restoran lain. & \\
\hline 20 & Anak saya tertarik 73.7\% \\
melakukan pembelian & \\
paket dan varian Chaki \\
Birthday party KFC \\
Jember karena item \\
yang ditawarkan \\
menarik untuk mereka. \\
\hline
\end{tabular}

Sumber : Data Olahan (2018)

Pernyataan nomor 1 sampai 5 adalah pernyataan untuk mengetahui apakah termasukperilaku pembelian yang rumit.pernyataan-pernyataan tersebut mewakili kepada deskripsi perilaku konsumen kepada varian paket Chaki Birthday Party yang ditawarkan KFC Jember.Seperti diketahui perilaku konsumen yang rumit terdiri dari tiga tahapan yaitu mengembangkan keyakinan terhadap produk, kedua, membangun sikap dan yang ketiga adalah membuat sebuah pilihan yang cermat (Assael, 2004).Item nomor 1 menyatakan tentang kepedulian konsumen terhadap produk.Persentase jawaban setuju dan sangat setuju yaitu $73.8 \%$ yang berarti konsumen tidak terlalu memperdulikan keberadaan iklan pada banner dan dinding KFC tanpa adanya promosi face-to-face.Item nomor 2 berisi pernyataan perbandingan informasi yang diterima anak ketika ia mengetahui produk paket ultah dari restoran lain. Persentase yang didapat untuk setuju dan tidak setuju juga cukup tinggi yaitu $63.7 \%$. Berarti sebanyak $63.7 \%$ persen konsumen mengenal paket ultah restoran lain dibandingkan paket KFC. Anak-anak antusias dan penasaran ketika ditawarkan produk paket Chaki dan varian item dengan persentase $78.7 \%$ dan 66.2 
$\%$. Sikap anak yang tidak langsung tertarik dengan penawaran adalah sebesar 53.6 $\%$.Total persentase dari sikap konsumen yang rumit adalah $67.2 \%$.Perilaku anak sebagai pembeli yaitu sebesar $67.2 \%$ menunjukkan perilaku rumit yang dapat diasumsikan sesuai dengan nature anak yang belum terlalu tegas dalam menentukan pilihan terutama dalam pembelian.

Kelompok pernyataan kedua yaitu pembelian pengurang ketidaknyamanan dimana pembeli pembeli akan berusaha membandingkan merk antar merk sehingga menemukan adanya perbedaan mutu. Mutu barang dipertimbangkan karena pembeli lebih mengutamakan kenyamanan yang akan diperoleh dengan harga yang bisa saja tinggi. Pernyataan nomor 6 berisi tentang ketertarikan anak dengan paket Chaki Birthday Party KFC Jember karena terpengaruh oleh penyampaian promosi dengan persentase setuju dan sangat setuju $46.6 \%$.Nomor 7 pernyataan berisi bahwa anak mengenal varian item hanya dengan melihat promosi pada banner dan dinding KFC sebesar $26.8 \%$. Nomor 8 berisi pernyataan bahwa anak memberikan perbandingan bahwa paket restoran lain lebih menarik sebesar $37.5 \%$. Sedangkan nomor 9 adalah pernyataan membandingkan dengan restoran lain sebesar $84.8 \%$. Nomor 10 berisi pernyataan dimana varian item yang ditawarkan sangat disukai anak-anak sebesar $87.8 \%$. Perilaku pembelian ini yaitu ditunjukkan dengan total persentase sebesar $56.7 \%$ yang menunjukkan bahwa anak-anak sebagai konsumen bukan termasuk konsumen yang berperilaku pengurang ketidaknyamanan karena mereka belumlah cerdas dalam menimbang mutu dan kenyamanan.
Kelompok pernyataan ketiga yaitu untuk mengetahui perilaku pembelian karena kebiasaan.Perilaku pembelian karena kebiasaan memang benar-benar melakukan pembelian berdasarkan kebutuhan yang memiliki dasar kegunaan sehingga applicable.Pernyataan nomor 11 berisi informasi ketertarikan anak dengan varian paket karena memberikan hiburan dan pebelajaran bagi mereka dengan persentasi setuju dan sangat setuju sebesar $74.2 \%$.Nomor 12 berisi pernyataan bahwa varian item pada acara ultah membuat pesta meriah dan menyenagkan dengan persentase setuju dan sangat setuju sebesar $77.4 \%$.Nomor 13 berisi pernyataan kegunaan varian item yang dapat digunakan untuk bermain setelah pesta usai sebesar 86.1\% yang menyatakan setuju dan sangat setuju.Nomor 14 menyatakan informasi bahwa anak sebagai konsumen akan merayakan ultah di KFC kembali setelah pernah melakukan perayaan ultah dengan pembelian paket Chaki sebesar $75 \%$. Item 15 menyatakan bahwa anak sebagai konsumen sudah lebih dari sekali melakukan pemblian varian dan paket Chaki Birthday party KFC Jember sebesar $33.7 \%$. Total dari persentase yang menunjukkan perilaku pembelian karena kebiasaan oleh anak-anak sebagai konsumen paket Chaki Birthday Party KFC Jember adalah 69.28 $\%$.

Kelompok terakhir yaitu pernyataan untuk mengetahui perilaku pembelian yang mencari variasi.Pada perlaku pembelian mencari variasi konsumen memiliki perilaku berbanding terbalik dengan perilaku pembelian karena kebiasaan yang frekuensinya biasa dilakukan. Konsumen dengan perilaku mencari variasi bahkan tidak akan melakukan pembelian secara regular. 
Mereka akan cepat melakukan perpindahan pada merk barang lain karena keinginan mencoba variasi baru. Pada pernyataan nomor 16 berisi informasi bahwa konsumen belum pernah memesan paket ultah tetapi langsung tertarik ketika mendapatkan tawaran promosi dari pihak KFC memperoleh persentase sebesar 68.3 $\%$.Item nomor 17 menunjukkan bahwa anak sebagai konsumen bersifat selektif dalam menentukan tempat perayaan ultahnya dinyatakan dengan persentase sebesar 70.3 \%.Item nomor 18 memberikan informasi bahwa anak akan memiliki keinginan untuk melakukan perayaan ultah setelah ditawarkan paket Chaki Birthday Party secara langsung oleh pihak KFC Jember sebesar $72.2 \%$. Nomor 19 berisi pernyataan bahwa setelah anak melakukan perayaan di KFC mereka selanjutnya ingin melakukan perayaan ultah di restoran lain sebesar 24.2\%. Dan item terakhir nomor 20 berisi pernyataan bahwa konsumen anak-anak tertarik melakukan pembelian paket dan varian Chaki Birthday party KFC Jember karena item yang ditawarkan menarik untuk mereka mendapat penilaian sebesar 73.7 $\%$. Total persentase $61.74 \%$ untuk perilaku pembelian mencari variasi.

Dalam kegiatan transaksi jual beli, faktor-faktor seperti strategi pemasaran/penjualan dan juga perilaku konsumen dapat sangat mempengaruhi satu sama lain. Logikanya adalah ketika strategi pemasaran/penjualan dilaksanakan dengan baik maka pastinya akan mempengaruhi perilaku konsumen dalam menentukan sikap pembelian barang atau jasa. Perilaku tersebut dapat berupa keputusan untuk membeli atau keputusan tidak jadi membeli barang atau jasa.Sehinggaakan

mempengaruhi penjualan yang akan mempengaruhi perolehan keuntungan produsen barang atau jasa.

Penelitian ini fokus kepada varian item yang ditawarkan pada paket Chaki Birthday Party KFC Jember dan perilaku pembelian anak-anak sebagai konsumen KFC Jember.Berhubungan dengan penjelasan sebelumnya bahwa strategi pemasaran/penjualan memiliki pengaruh terhadap perilaku konsumen, maka diadakanlah sebuah studi dengan mensurvei perilaku pembelian anak-anak terhadap paket Chaki Birthday Party KFC Jember dan juga penilaian orang tua yang mewakili anak mereka dalam memberikan pendapatnya mengenai varian item Chaki Birthday Party KFC Jember.

KFC merupakan sebuah usaha waralaba yang menargetkan seluruh lapisan masyarakat termasuk usia anak-anak. Varian menu menjangkau anak-anak sebagai salah satu tipe konsumen KFC.Paket menu untuk anak serta penawaran paket perayaan ulang tahun menunjukkan KFC menganggap penting kontribusi anak-anak sebagai konsumennya.Seperti halnya dinyatakan oleh Hill dan Tilley (2002) bahwa tim marketing penjual makanan menargetkan anak-anak sebagai salah satu konsumen melalui promosi melalui media Televisi setelah jam sekolah dan hari minggu pagi.Hal ini terlihat dari tawaran pake ultah yang terdiri dari dua jenis paket. Chaki Birthday Party dengan dua jenis paket yang ditawarkan berupa paket tematik, dan paket funtastic. Jika melihat bagian menu di situs www.kfcku.com maka ada pilihan kids yang sengaja di khususkan untuk kids party (pesta untuk anak-anak) (www.kfcindonesia.com). Keragaman penawaran item yang ditawarkan dapat disimpulkan sebagai 
salah satu cara pihak KFC sebagai penjual untuk menarik minat beli anak-anak yang juga diperhitungkan sebagai konsumen KFC Jember. Dua paket yang ditawarkan di lengkapi dengan item yang berbeda yang di sesuaikan dengan minat anak berdasarkan kondisi psikologis anak yang berbeda berupa kesesuaian ketertarikan pada tema.Hal ini didasarkan pada sifat alami anak yang cenderung puas dan menyukai visual merchandise yang menarik seperti pada penelitian yang dilakukan oleh Natadjaja, Dewi, F dan Setyawan (2010) terhadap visual merchandise McDonald dan perilaku pembelian paket Happy Meal. Disamping visual merchandise, perilaku pembelian juga dapat dipengaruhi visual dalam bentuk display produk yang berupa posisi dan gaya penataan produk untuk memamerkan barang. Display produk yang menarik ternyata juga mampu menarik minat pembeli dengan menyediakan rangkuman informasi tentang barang yang dipajang atau dijual sehingga menimbulkan impulsive buying (Melati, 2012). Tentunya varian item yang ditawarkan KFC ini juga mengandung konsep yang menunjang unsur visual karena tema dan item yang ditawarkan berusaha menarik minat anak-anak yang melihatnya.

Dalam analisis angket, orang tua berpendapat bahwa anak mereka sebesar $70.37 \%$ menyatakan ketertarikan dan rasa suka terhadap varian item Chaki Birthday Party KFC Jember baik oleh anak yang hanya diberikan penawaran maupun anak-anak yang telah melakukan pembelian paket. Varian item yang terlihat oleh anak-anak tentunya berhubungan dengan peran otak yang menjadi tempat pemrosesan informasi yang kemudian mempengaruhi sebuah tingkah laku yang terkontrol (controlled behavior) (Hutchinson, Lu \& Weingarten, n.d).Angka tersebut termasuk dalam kategori baik dan pihak KFC telah melakukan trik-trik penjualan yang menargetkan anak-anak dengan penjualan mainan, dan alat sekolah yang dihadirkan pada paket Birthday Party.Hal ini yang disebut manipulasi pasar dan anak-anak adalah sasaran empuk dari manipulasi ini.

Seperti halnya Amerika sekitar 57 juta anak usia remaja menghabiskan sekitar \$100 miliar tiap tahun dengan membelanjakan uang keluarga untuk membeli makanan, jajanan, minuman, video, produk elektronik, mainan, film, olahraga, baju dan sepatu. Selanjutnya, anak-anak usia 12 kebawah juga menghabiskan \$11 miliar untuk belanja makanan dan juga alat rumah tangga lainnya (Beder, 1998). Penjual produk tentu saja sudah menargetkan anak-anak karena orang tua akan menuruti kehendak anak mereka dalam kegiatan promosi yang dilakukan. Seperti diketahui bahwa promosi adalah untuk mendapatkan pedoman tentang cara perusahaan mencapai tujuan/target bisnis (Haryadi, 2005). Hal ini dapat terlihat bahwa anak-anak telah menjadi target bisnis dalam melaksanakan promosi.

Dalam penelitian ini pendapat varian item ini dihubungkan dengan perilaku pembelian anak-anak sebagai konsumen KFC Jember.Data angket 69.28 $\%$ merupakan persentase tertinggi yang menunjukkan perilaku pembelian oleh anak-anak yang bersifat kebiasaan.Sehingga dapat disimpulkan bahwa varian item yang menarik dan beragam dapat menarik minat anak untuk secara berkelanjutan atau memiliki loyalitas terhadap keinginan membeli dan 
melakukan lagi pembelian paket Chaki Birthday Party di KFC Jember.

\section{PENUTUP}

\section{Kesimpulan}

Penelitian ini sengaja dilakukan dengan pemilihan sampling secara accidental pada konsumen KFC yang sedang melakukan pembelian di KFC Jember. Hal ini dimaksudkan agar hasil penelitian yang diperoleh menjadi pertimbangan oleh penjual, dalam hal ini pihak KFC Jember, untuk lebih meningkatkan strategi penjualan yang akan lebih menarik minat pembeli paket Chaki Birthday.

Perilaku anak sebagai pembeli yaitu sebesar $67.2 \%$ menunjukkan perilaku rumit yang dapat diasumsikan sesuai dengan nature anak yang belum terlalu tegas dalam menentukan pilihan terutama dalam pembelian. Perilaku pembelian dengan total persentase sebesar $56.7 \%$ menunjukkan bahwa anak-anak sebagai konsumen bukan termasuk konsumen yang berperilaku pengurang ketidaknyamanan karena mereka belumlah cerdas dalam menimbang mutu dan kenyamanan. Total dari persentase yang menunjukkan perilaku pembelian karena kebiasaan oleh anak-anak sebagai konsumen paket Chaki Birthday Party KFC Jember adalah $69.28 \%$.Sedangkan total persentase untuk perilaku pembelian mencari variasi adalah $61.74 \%$.Perilaku mayoritas anak-anak dalam menetukan perilaku pembelian dikategorikan sebagai perilaku pembelian karena kebiasaan sebesar 69.28\%.Sehubungan dengan varian item yang ditawarkan dan dipromosikan pihak KFC Jember $70.37 \%$ menunjukkan ketertarikan dan antusias pada varian item paket Chaki Birthday Party.Sehingga ketertarikan dan antusias terhadap varian item paket Chaki Birthday Partymendorong perilaku pembelian karena kebiasaan karena bentuk kenyamanan dan sisi loyalitas anak-anak sebagai konsumen atau calon konsumen paket Chaki Birthday Party.

\section{Saran}

Pada akhirnya, strategi promosi dan penjualan yang dilakukan pihak KFC Jember cukup efektif dalam membuat konsumen anak-anak berperilaku pembelian karena kebiasaan. Meskipun begitu angka yang ditunjukkan dengan $69.28 \%$ belum terlalu baik untuk membuat anak loyal terhadap paket Chaki Birthday Party sehingga hal ini akan menjadi catatan KFC Jember untuk melakukan strategi yang lebih baik lagi dalam menarik minat anak.

\section{DAFTAR PUSTAKA}

Assael, H. (2004). Consumer behavior: a strategic approach. Pennsylvania: Pennsylvania State University.

Beder, S. (1998). Marketing to children. 'A Community View', Caring for Children in the Media Age, Papers from a national conference, edited by John Squires and Tracy Newlands, New College Institute for Values Research, Sydney, 101-111, dari https://www.uow.edu.au/ sharonb /children.html

Cannon, J. P., Perreault, W. D., dan McCarthy, E. J. (2008). Pemasaran dasar (Ed.16). Jakarta: Salemba Empat.

Churchill, G. A. (2005). Dasar-dasar riset pemasaran (Ed 4). Jakarta: Erlangga

Haryadi, A. (2005). Kiat membuat promosi penjualan secara efektif 
dan terencana. Jakarta: PT Elex Media Komputindo.

Hill, H. and Tilley, J. (2002), Packaging of children's breakfast cereal.British Food Journal.104 ( 9), 766-77.

Hutchinson, J.W, Lu, J \& Weingarten, E. (n.d).Visual attention in consumer settings. Diakses 10 Juni 2017 dari https://faculty.wharton.upenn.edu/ wp-content/uploads/2016/06/Visu al_Attention_in_Consumer_Settin gs_IHCP_150814.pdf

KFC Indonesia. (n.d). Kids party, diakses pada 10 Maret 2017 dari www.kfcku.com

KFC Indonesia. (n.d). Kegiatan usaha perusahaan, diakses pada 15 Maret 2017 dari http://www.kfcindonesia.com/kegi atan-usaha-perusahaan

Melati, I. (2012). Pengaruh display produk pada keputusan pembelian konsumen. Binus Business Review. 3 (2), 875-881.

Mulia, E. (2015). Power sales: Rahasia sukses memimpin tim penjualan. Jakarta: PT Elex Media Komputindo.

Natadjaja, L, Dewi.F, R dan Setyawan, D. (2010). Studi pengaruh visual merchandise untuk anak terhadap perilaku pembelian paket HappyMeal di restoran McDonald's Surabaya.Jurnal Desain Komunikasi Visual Nirmana, 11 (1), 41-59, doi:https://doi.org/10.9744/nirman a.11.1.pp. 41-59

Rangkuti, F. (2009). Mengukur efektivitas program promosi dan analisis kasus menggunakan SPSS. Jakarta: PT Gramedia Pustaka Utama.

Rangkuti, F. (2009). Strategi promosi yang kreatif dan analisis kasus integrated marketing

communication. Jakarta: PT Gramedia Pustaka Utama.

Ratnasari, A, Hamdan.Y dan Julia, A. (2001).Promosi penjualan produk melalui instagram.Jurnal Komunikasi, 2 (2), 101-107. Diakses 8 Maret 2017 dari https://www.interstudi.edu/journal /index.php/InterKomunika/article/ view/8/pdf

Setiadi, N. J. (2015). Perilaku konsumen. Jakarta: Kencana Prenada Media Group.

Simamora, B. (2008). Panduan riset perilaku konsumen. Jakarta: PT Gramedia Pustaka Utama.

Sugiyono. (2006). Metode penelitian bisnis. Bandung: CV Alvabeta

Suharyadi, Nugroho, A, S.K, Purwanto dan Faturohman, M. (2007). Kewirausahaan. Jakarta: Salemba Empat. 